\title{
Performans Keturunan Ayam Arras dengan Ayam Arab (Ayam Ketarras) Umur 2-12 Minggu
}

\author{
Performance of Arras Chicken Descendants with Arab Chicken (Ketarras) Aged 2-12 Weeks

\section{E. Gunawan, D. Kaharuddin, dan Kususiyah}

\author{
Jurusan Peternakan, Fakultas Pertanian, Universitas Bengkulu \\ Jalan Raya, W.R Supratman, Kandang Limun, Bengkulu, 38371 \\ Email: Edogunawan720@gmail.com
}

\begin{abstract}
The objective of this study was to evaluate the performance of Arab descendants with Arras Chicken (Ayam Ketarras) age 2-12 weeks. This research has been conducted for 6 months, starting from 25 June to 25 December 2016 in CZAL. The treatments were chicken type with P0 $=$ Ketarras chicken and P1 = Arabian chicken. This study used $t$ test analysis with 2 treatments 15 replications. Each replication used 2 chickens, so each type of chicken required 30 tails. The variables observed were, consumption of ration, growth, and conversion of rations. T test results showed that the cumulative feed intake during the study for both types of chicken had no significant effect $(t<t$ table) except at weeks 2-7 and 2-8 ( $t>t$ table). The consumption of cumulative chicken ration at age 2-7 and 2-8 is higher than Ketarras chicken. Cumulative feed consumption at the age of 2-12 weeks of chicken feed consumption of Arab chicken ( $3474.70 \mathrm{~g}$ ) was not significant compared to Ketarras chickens $(3453.30 \mathrm{~g})$. The mean weight gain during the study of the two different types of chickens was not significant $(\mathrm{t}$ count $<\mathrm{t}$ table) except the 2nd, 11th and 12th week of weight. Arab chicken weights age 11 and 12 weeks were higher than Ketarras chicken. The weight gain of both types of chicken age 2-12 weeks weight were Arab chicken $(815.60 \mathrm{~g})$ and Ketarras chicken $(753.23 \mathrm{~g})$. The average weight gain of both chickens were significantly different ( $\mathrm{t}$ count $>\mathrm{t}$ table) except at age 2-3, and 2-8 weeks. However, weight gain during the age of 2-12 weeks at the Arab chicken was significantly higher than Ketarras chicken, that chicken Arab (718.83 g) and Ketarras chicken $(645.07 \mathrm{~g})$. Cumulative feed conversion both types of chicken had no significant effect $(\mathrm{t}$ $<t$ table) except at the age of 2-9, 2-10, 2-11, and 2-12 weeks. Ketarras chicken ration conversion was higher than Arab chicken. The overall ration conversion of both chicken types 2-12 weeks in Ketarras chicken (5.38) was significantly different than that of Arabian chickens (4.88). Cumulatively, during the age of 2-12 weeks, the consumption of chicken ration of Ketarras were not significantly different in weight gain, which is lower than that of Arabian chickens. Cumulative ration conversion of Ketarras chicken at 2-12 weeks of age was significantly higher than Arab chickens.
\end{abstract}

Key words: performance, growth, Arab chicken, Ketarras chicken

\begin{abstract}
ABSTRAK
Penelitian ini bertujuan untuk mengevaluasi performans keturunan ayam Arab dengan ayam Arras (Ayam Ketarras) umur 2-12 minggu. Penelitian ini telah dilaksanakan selama 6 bulan, dimulai sejak 25 Juni sampai 25 Desember 2016 di CZAL. Perlakuan yang dicobakan adalah jenis ayam dengan P0 = ayam Ketarras dan P1 = ayam Arab. Penelitian ini menggunakan analisis Uji t dengan 2 perlakuan 15 ulangan. Setiap ulangan menggunakan 2 ekor ayam, sehingga masing-masing jenis ayam yang dibutuhkan 30 ekor. Variabel yang diamati adalah, konsumsi ransum, pertumbuahan, dan konversi ransum. Hasil uji t menunjukkan bahwa konsumsi ransum kumulatif kedua jenis ayam selama penelitian berbeda tidak nyata ( $\mathrm{t}$ hitung $<\mathrm{t}$ tabel) kecuali pada minggu ke 2-7 dan 2-8 (t hitung $>t$ tabel). Konsumsi ransum kumulatif ayam arab pada umur 2-7 dan 2-8 lebih tinggi dibandingkan ayam Ketarras. Konsumsi ransum kumulatif pada umur 2-12 minggu konsumsi ransum ayam Arab $(3474,70 \mathrm{~g})$ berbeda tidak nyata dibandingkan ayam Ketarras $(3453,30 \mathrm{~g})$. Rataan berat badan selama penelitian dari kedua jenis ayam berbeda tidak nyata ( $t$ hitung $<\mathrm{t}$ tabel) kecuali berat badan minggu ke 2, 11 dan 12 minggu. Berat badan ayam Arab umur 11 dan 12 minggu lebih tinggi dibanding ayam Ketarras. Capaian berat badan kedua jenis ayam umur 2-12 minggu berat badan ayam Arab (815,60 g) dan ayam Ketarras $(753,23 \mathrm{~g})$. Rataan pertambahan berat badan kedua jenis ayam berbeda nyata (t hitung $>\mathrm{t}$ tabel) kecuali umur 2-3, dan 2-8 minggu. Namun demikian pertambahan berat badan selama umur 2-12 minggu pada ayam Arab nyata lebih tinggi dibandingkan ayam Ketarras, yaitu ayam Arab (718,83 g) dan ayam Ketarras (645,07 g). Konversi ransum kumulatif kedua jenis ayam berbeda tidak nyata (t hitung $<\mathrm{t}$ tabel) kecuali pada umur 2-9, 2-10, 2-11, dan 2-12 minggu. Konversi ransum ayam Ketarras lebih tinggi dibanding ayam Arab. Konversi ransum secara
\end{abstract}

Performans Keturunan Ayam Arras dengan Ayam Arab Umur 2-12 Minggu (Gunawan et al., 2018)| 89 
keseluruhan kedua jenis ayam 2-12 minggu pada ayam Ketarras $(5,38)$ berbeda nyata lebih tinggi dibandingkan dengan ayam Arab $(4,88)$. Secara kumulatif, selama umur 2-12 minggu, konsumsi ransum ayam Ketarras berbeda tidak nyata dengan capaian berat badan, pertambahan berat badan, yang lebih rendah dibanding ayam Arab. Konversi ransum kumulatif ayam Ketarras umur 2-12 minggu nyata lebih tinggi dibanding ayam Arab.

Kata kunci : performans, pertumbuhan, ayam Arab, ayam Ketarras

\section{PENDAHULUAN}

Kebutuhan protein hewani khususnya telur masih belum tercukupi untuk masyarakat Indonesia. Data statistik menunjukkan bahwa konsumsi telur ayam ras/kampung masyarakat Indonesia sudah mencapai 1983 gram/kapita/minggu (BPS, 2016). Permintaan akan protein hewani ini semakin meningkat seiring bertambahnya jumlah penduduk, tingkat pendapatan dan kesadaran akan gizi yang semakin membaik. Telur ayam kampung saat ini sangat digemari masyarakat tetapi kemampuan produksinya masih terbatas, ayam kampung hanya mampu memproduksi telur 39-130 butir per tahun (Binawati, 2008). Kelebihan ayam kampung ini merupakan tipe ayam dwiguna sebagai produksi telur dan daging. Kelemahan dari ayam ini adanya aktivitas mengeram dan mengasuh anak yang lama serta produksi telur yang rendah (Sulandari, 2007). Kepemilikan ayam kampung masih dalam jumlah sedikit, dan pemeliharaannya belum dalam skala besar.

Permintaan konsumen akan telur ayam kampung dewasa ini disikapi oleh peternak dengan memelihara ayam Arab sebagai pengganti telur ayam kampung. Ayam Arab (Gallus turcicus) berasal dari ayam hutan dan merupakan salah satu ayam buras yang sudah beradaptasi di Indonesia. Ayam ini bersifat gesit, aktif dan memiliki daya tahan tubuh yang kuat (Darmana dan
Sitanggang, 2002). Ayam Arab mulanya kurang mendapat perhatian dari para peternak. Ayam Arab mulai dikembangkan dan ditingkatkan produksinya, karena ayam Arab termasuk salah satu jenis ayam penghasil telur yang cukup potensial karena produksi telurnya tinggi menyerupai produktivitas ayam ras petelur dan memiliki karakteristik telur yang menyerupai ayam kampung. Produksi telur ayam Arab tergolong tinggi yaitu 190-250 butir/tahun dengan bobot telur rata- rata 30-35g/butir. Umur pertama bertelur ayam Arab berkisar antara 135-150 hari, kandungan protein telur ayam arab sebesar 20,05\%, dan kadar lemak rendah sebesar 7,81\%. Ayam Arab tidak memiliki sifat mengeram sehingga waktu bertelurnya menjadi lebih panjang (Iskandar dan Sartika, 2008).

Hasil persilangan ayam Arab dengan ayam Ras petelur yaitu ayam Arras (50\% ayam Arab 50\% ayam Ras petelur) menunjukkan bahwa produksi telurnyacukup baik, namun warna kerabang telur ayam Arras yang dihasilkanlebih dominan menyerupai warna kerabang telur ayam Ras, sehingga masih mempunyai nilai harga jual yang lebih rendahdibanding dengan harga telur ayam Kampung. Agar dominasi warna kerabang telur dari ayam Ras petelur yang dihasilkan berkurang, maka ayam Arras perlu disilangkan kembali dengan ayam Arab, hasil persilangan ini dinamakan ayam Ketarras (keturunan dari 
ayam Arab jantan dengan ayam Arras betina) yang memiliki darah $25 \%$ ayam Ras petelur coklat dan $75 \%$ ayam Arrab.

Performans ayam Ketarras belum diketahui keunggulannya karena merupakan hasil penetasan pertama. Untuk melihat performans produksi hasil dari persilangan ini, tentu tidak terlepas dari pemeliharaan fase starter, karena fase starter ini sangat penting bagi keberlangsungan hidup ayam untuk fase-fase selanjutnya.

Fase kritis pemeliharaan ayam petelur adalah pada awal pemeliharaan (periode starter). Keberhasilan menciptakan kondisi yang optimal bagi tumbuh kembang anak ayam hingga pullet menjadi modal dasar suksesnya peternakan ayam petelur (Rasyaf, 2008). Menurut Pambudhi (2003) disitasi oleh Diana (2012) periode starter pada ayam Arab terdiri dari dua fase yaitu fase starter I umur 1-6 minggu dan fase stater II umur 7-12 minggu. Fase starter ini sangat penting karena fase ini dapat mempengaruhi pada saat fase-fase selanjutnya. Apabila salah dalam pemeliharaan fase starter ini dapat menyebabkan mudahnya terserang penyakit, dan produktivitasnya rendah.

Penelitian ini bertujuan untuk mengevaluasi performans keturunan ayam Arab dengan ayam Arras (Ayam Ketarras) umur 2-12 minggu. Hipotesis penelitian ini adalah Performans keturunan ayam Arab dengan ayam Arras (Ayam Ketarras) diduga lebih baik dibandingkan ayam Arab pada umur 2 - 12 minggu (Fase Starter).

\section{MATERI DAN METODE}

Penelitian ini telah dilaksanakan selama 6 bulan, dimulai sejak 25 Juni sampai 25 Desember di CZAL. DOC diperoleh dari hasil penetasan sendiri. Telur tetas diperoleh dari hasil menyilangkan sendiri dilaksanakan di Commercial Zone Animal Laboratory.

Materi yang digunakan dalam penelitian adalah mesin tetas, kandang pemeliharaan, kandang brooder, Alat penetasan, timbangan digital, desinfektan, ember, tempat pakan, dan tempat minum ternak. Bahan yang digunakan dalam penelitian ini adalah indukan ayam Arras dan pejantan ayam Arab. Bahan yang digunakan, adalah ransum komersial BR1, KLK (Konsentrat Layer Khusus), dedak, dan jagung giling.

Tahapan penelitian ini terbagi menjadi 3 yaitu: mengawinkan ayam Arab Silver pejantan dengan ayam Ras petelur coklat betina, menetaskan telur, persiapan kandang dan pemeliharaan ayam. Dalam pemeliharaan ayam umur 0-2 minggu dimasukkan ke dalam kandang brooder untuk pengganti indukan. Awal minggu ke3 pemeliharaan ayam dalam perlakuan dengan PK 18\% dan energi $2.800 \mathrm{kkal} / \mathrm{kg}$ (NRC, 1994).

Ransum yang digunakan yaitu campuran KLK Super, dedak dan jagung giling. Ransum ditambahkan setiap pagi dan sore hari. Penimbangan dilakukan setiap 1 minggu sekali untuk mengetahui pertumbuhan berat badannya dan dilakukan sampai minggu ke-12. Penelitian ini menggunakan 2 perlakuan dan 15 ulangan. 
Faktor jenis ayam digunakan sebagai perlakuan, yaitu: $\mathrm{P} 0$ = ayam Ketarras dan $\mathrm{P} 1=$ ayam Arab. Setiap ulangan menggunakan 2 ekor ayam, sehingga masing-masing jenis ayam dibutuhkan 30 ekor ayam yang ditempatkan secara acak pada kandang batteray.

Tabel 1. Kandungan nutrisi bahan penyusun ransum

\begin{tabular}{lllllll}
\hline Bahan Ransum & $\mathrm{PK}(\%)$ & $\mathrm{ME}(\mathrm{kkal} / \mathrm{kg})$ & $\mathrm{SK}(\%)$ & Lemak $(\%)$ & $\mathrm{Ca}(\%)$ & $\mathrm{P}(\%)$ \\
\hline Dedak $^{\text {a }}$ & 11,9 & 2460 & 12 & 9,78 & 0,01 & 1,3 \\
Jagung $^{\text {a }}$ & 8,9 & 3321 & 2,5 & 2,97 & 0,02 & 0,23 \\
$\mathrm{KLK}^{\mathrm{b}}$ & 33 & 2700 & 9,83 & 6,37 & 10,87 & 1,28 \\
BR1 $^{\mathrm{c}}$ & 21 & 2900 & 4,5 & 4 & 1 & 0,8
\end{tabular}

a. Hartadi et al. (2005), b. Label KLK (PT. Japfa Comfeed), c. Label BR1

Variabel yang diamati meliputi pertambahan berat badan kumulatif, konsumsi ransum mingguan, konsumsi konversi ransum kumulatif, dan konversi ransum kumulatif, berat badan mingguan, ransum kumulatif.

pertambahan berat badan mingguan,

Tabel 2. Komposisi dan kandungan nutrisi ransum umur 0-12 dan umur 2-12 minggu

\begin{tabular}{lll}
\hline Kandungan Pakan & $0-2$ minggu & $2-12 \mathrm{minggu}$ \\
\hline BR 1 & $75,5 \%$ & - \\
KLK & - & $35 \%$ \\
Dedak & - & $35 \%$ \\
Jagung giling & $24,5 \%$ & $30 \%$ \\
\hline Jumlah & $100 \%$ & $100 \%$ \\
\hline Protein Kasar & $18,1 \%$ & $18,07 \%$ \\
Energi & $3003,1 \mathrm{kkal} / \mathrm{kg}$ & $2802,3 \mathrm{kkal} / \mathrm{kg}$ \\
Serat Kasar & $4,01 \%$ & $7,40 \%$ \\
Lemak Kasar & $3,74 \%$ & $6,54 \%$ \\
Kalsium & $0,75 \%$ & $3,85 \%$ \\
Fosfor & $0,48 \%$ & $0,97 \%$ \\
\hline
\end{tabular}

$$
\text { Data konsumsi ransum, } \quad \mathrm{S}_{\mathrm{gab}}=\sqrt{\left(\mathrm{SS}_{1}+\mathrm{SS}_{2}\right) /\left(\mathrm{r}_{1}+\mathrm{r}_{2}-2\right)}
$$

pertambahan berat badan, dan konversi ransum yang diperoleh dianalisis Keterangan :

menggunakan uji $\mathrm{t}$ dengan kepercayaan $\mathrm{t} \quad$ : Uji $\mathrm{t}$ 95\% (Astuti, 2007).

$\mathrm{t}=\left(\overline{\mathrm{y}}_{1}-\overline{\mathrm{y}}_{2}\right) / \mathrm{S}_{\mathrm{gab}} \sqrt{1 / \mathrm{r}_{1}+1 / \mathrm{r}_{2}} \quad \overline{\mathrm{y}}_{2} \quad:$ Rataan Perlakuan 2 
$\mathrm{r}_{1} \quad$ : Jumlah ulangan perlakuan 1

$\mathrm{r}_{2} \quad$ : Jumlah ulangan perlakuan 2

$\mathrm{S}_{\text {gab }} \quad$ : Student's t test gabungan

$\mathrm{SS}_{1} \quad$ : Jumlah kuadrat perlakuan 1

$\mathrm{SS}_{2}$ : Jumlah kuadrat perlakuan 2

Untuk mendapatkan nilai SS

menggunakan rumus sebagai berikut :

$\mathrm{SS}=\left(\sum_{\mathrm{i}=1}^{\mathrm{n}} \mathrm{x}_{1}^{2}\right)-\left(\sum_{\mathrm{i}=1}^{\mathrm{n}} \mathrm{x}_{1}\right)^{2} / \mathrm{n}$

Keterangan :

SS : Jumlah kuadrat $\left(\sum_{i=1}^{\mathrm{n}} \mathrm{x}_{1}^{2}\right): \begin{aligned} & \text { Penjumlahan dari kuadrat nilai } \\ & \text { hasil pengamatan }\end{aligned}$ $\left(\sum_{i=1}^{\mathrm{n}} \mathrm{x}_{1}\right)^{2}: \begin{aligned} & \text { Kuadrat dari hasil penjumlahan } \\ & \text { pengamatan }\end{aligned}$

n : Jumlah ulangan

\section{HASIL DAN PEMBAHASAN}

\section{Konsumsi Ransum}

Konsumsi ransum didapatkan dari banyaknya ransum yang diberikan dikurang dengan sisa ransum. Rataan konsumsi ransum kumulatifayam Ketarras dan ayam Arab penelitian dapat dilihat pada Tabel 3 .

Tabel 3. Rataan konsumsi ransum kumulatif ayam Ketarras dan ayam Arab

\begin{tabular}{|c|c|c|c|}
\hline \multirow{2}{*}{$\begin{array}{c}\text { Minggu } \\
\text { ke- }\end{array}$} & \multicolumn{2}{|c|}{ Konsumsi } & \multirow[b]{2}{*}{ Keterangan } \\
\hline & P0 & $\mathrm{P} 1$ & \\
\hline & \multicolumn{2}{|c|}{---------------- gram/ekor ---------------- } & \\
\hline $2-3$ & $135,57^{\mathrm{a}} \pm 5,91$ & $136,57^{\mathrm{a}} \pm 5,42$ & ns \\
\hline $2-4$ & $396,83^{a} \pm 14,82$ & $405,00^{\mathrm{a}} \pm 7,96$ & $\mathrm{~ns}$ \\
\hline $2-5$ & $671,13^{a} \pm 20,83$ & $684,77^{\mathrm{a}} \pm 9,97$ & ns \\
\hline $2-6$ & $1040,53^{a} \pm 16,59$ & $1055,90^{\mathrm{a}} \pm 11,77$ & $\mathrm{~ns}$ \\
\hline $2-7$ & $1405,87^{\mathrm{a}} \pm 24,44$ & $1426,27^{b} \pm 13,54$ & $*$ \\
\hline $2-8$ & $1793,63^{a} \pm 26,42$ & $1818,43^{b} \pm 17,37$ & * \\
\hline $2-9$ & $2185,67^{\mathrm{a}} \pm 29,68$ & $2209,10^{\mathrm{a}} \pm 19,63$ & ns \\
\hline $2-10$ & $2601,13^{\mathrm{a}} \pm 30,07$ & $2624,97^{\mathrm{a}} \pm 19,87$ & ns \\
\hline $2-11$ & $3016,87^{\mathrm{a}} \pm 29,67$ & $3038,50^{\mathrm{a}} \pm 21,61$ & ns \\
\hline $2-12$ & $3453,30^{\mathrm{a}} \pm 29,64$ & $3474,70^{\mathrm{a}} \pm 22,22$ & ns \\
\hline
\end{tabular}

Keterangan :

\footnotetext{
P0 = Keturunan ayam Arab dengan ayam Arras (Ayam Ketarras)

P1 = Ayam Arab

$\mathrm{ns}=$ Perlakuan berbeda tidak nyata ( $\mathrm{t}$ hitung $<\mathrm{t}$ tabel)

$* \quad=$ Perlakuan berbeda nyata $(\mathrm{t}$ hitung $>\mathrm{t}$ tabel $)$
}

Hasil uji $\mathrm{t}$ menunjukkan bahwa konsumsi ransum kumulatif kedua jenis ayam selama penelitian berbeda tidak nyata ( $\mathrm{t}$ hitung $<\mathrm{t}$ tabel) kecuali pada minggu ke 2-7 dan 2-8 (t hitung >t tabel). Terlihat dari tabel tersebut bahwa konsumsi ransum kumulatif ayam arab pada umur 2-7 dan 2-8 lebih tinggi dibandingkan ayam Ketarras. Konsumsi ransum kumulatif pada umur 2-12 minggu konsumsi ransum ayam Arab (3474,70 g) berbeda tidak nyata dibandingkan ayam Ketarras (3453,30 g). Menurut Nur (2016), konsumsi ransum ayam Arras umur 2-12 minggu yaitu ayam Arras sebesar 2960,92g/ekor dan ayam Arab 2975,58 g/ekor. Menurut Astuti (2012) konsumsi ransum dipengaruhi selain faktor ukuran 
tubuh, dan kualitas ransum yang diberikan, juga jenis ayam. Kualitas ransum yang digunakan pada pemeliharaan ini sama. Ayam Ketarras merupakan hasil persilangan ayam Arab jantan dengan ayam Arras betina yang menghasilkan jenis ayam yang memiliki darah $75 \%$ ayam Arab dan 25\% ayam Ras petelur coklat, dari komposisi tersebut dapat diartikan bahwa ayam Ketarras memiliki tingkat konsumsi ransum yang hampir menyerupai ayam Arab sebagai ayam Petelur tipe ringan.

Tidak terdapatnya perbedaan yang nyata konsumsi ransum masing-masing jenis ayam dapat dilihat pada Gambar 1.

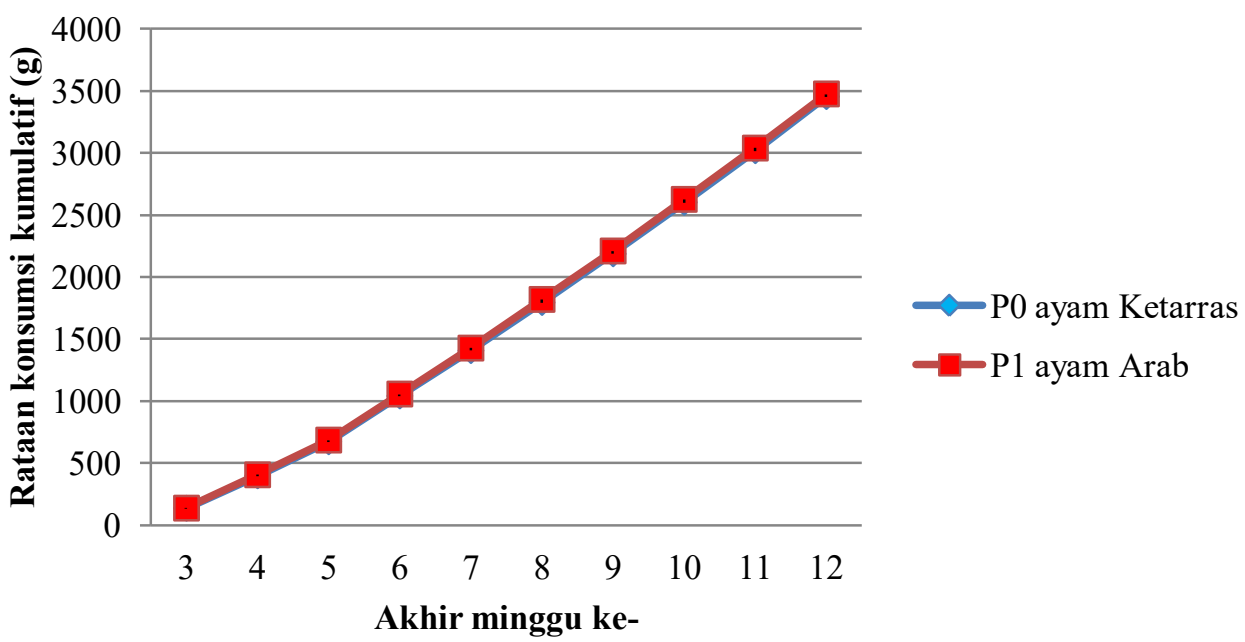

Gambar 1. Konsumsi ransum mingguan ayam Ketarras dan ayam Arab

Terlihat dari Gambar 1. bahwa, konsumsi ransum mingguan dari masingmasing jenis ayam relatif meningkat dengan bertambahnya umur ayam. Menurut Sukarini dan Rifai (2011) konsumsi ransum dibutuhkan untuk memenuhi kebutuhan energi hidup pokok dan selebihnya akan digunakan untuk pertumbuhan dan proses produksi telur.

\section{Pertumbuhan}

Pertumbuhan pada ayam meliputi berat badan, pertambahan berat badan mingguan dan pertambahan berat badan kumulatif.

\section{Berat Badan}

Penimbangan berat badan dilakukan secara rutin setiap minggu sejak umur 2-12 minggu. Rataan berat badan mingguan masing-masing jenis ayam selama penelitian dapat dilihat pada Tabel 4. 
Tabel 4. Rataan berat badan mingguan ayam Ketarras dan ayam Arab selama penelitian

\begin{tabular}{cccc}
\hline \multirow{2}{*}{$\begin{array}{c}\text { Akhir minggu } \\
\text { ke- }\end{array}$} & \multicolumn{2}{c}{ Berat badan } & \\
\cline { 2 - 3 } 2 & - Keterangan $^{-}$ & $\mathrm{P} 1$ & $*$ \\
3 & $108,17^{\mathrm{a}} \pm 11,46$ & $96,77^{\mathrm{b}} \pm 6,74$ & $\mathrm{~ns}$ \\
4 & $141,83^{\mathrm{a}} \pm 11,97$ & $136,93^{\mathrm{a}} \pm 8,43$ & $\mathrm{~ns}$ \\
5 & $189,70^{\mathrm{a}} \pm 15,86$ & $194,20^{\mathrm{a}} \pm 16,30$ & $\mathrm{~ns}$ \\
6 & $264,17^{\mathrm{a}} \pm 26,06$ & $276,93^{\mathrm{a}} \pm 16,07$ & $\mathrm{~ns}$ \\
7 & $326,00^{\mathrm{a}} \pm 26,22$ & $343,50^{\mathrm{a}} \pm 26,09$ & $\mathrm{~ns}$ \\
8 & $407,50^{\mathrm{a}} \pm 34,45$ & $432,13^{\mathrm{a}} \pm 38,36$ & $\mathrm{~ns}$ \\
9 & $480,13^{\mathrm{a}} \pm 44,32$ & $503,90^{\mathrm{a}} \pm 47,15$ & $\mathrm{~ns}$ \\
10 & $549,27^{\mathrm{a}} \pm 60,08$ & $599,40^{\mathrm{a}} \pm 53,87$ & $\mathrm{~ns}$ \\
11 & $612,27^{\mathrm{a}} \pm 51,93$ & $660,13^{\mathrm{a}} \pm 60,55$ & $*$ \\
12 & $689,90^{\mathrm{a}} \pm 49,71$ & $744,87^{\mathrm{b}} \pm 62,72$ & $*$ \\
\hline
\end{tabular}

Keterangan :

P0 = Keturunan ayam Arab dengan ayam Arras (Ayam Ketarras)

$\mathrm{P} 1=$ Ayam Arab

$\mathrm{ns}=$ Perlakuan berbeda tidak nyata $(\mathrm{t}$ hitung $<\mathrm{t}$ tabel $)$

$*$ = Perlakuan berbeda nyata $(\mathrm{t}$ hitung $>\mathrm{t}$ tabel $)$

Hasil uji $\mathrm{t}$ menunjukkan bahwa rataan berat badan selama penelitian dari kedua jenis ayam berbeda tidak nyata $(\mathrm{t}$ hitung $<\mathrm{t}$ tabel) kecuali berat badan minggu ke 2, 11 dan 12 minggu.Terlihat dari tabel tersebut bahwa berat badan ayam Arab umur 11 dan 12 minggu lebih tinggi dibanding ayam Ketarras. Akumulasi berat badan kedua jenis ayam mulai di dominasi oleh ayam Arab yang memiliki berat lebih tinggi dibandingkan ayam Ketarras pada minggu ke-4 sampai minggu ke-12, dan pada saat pengambilan sampel tidak dapat dilakukan seksing karena pada umur 2 minggu jenis kelamin kedua jenis ayam belum dapat dibedakan sehingga terdapat banyak jenis kelamin jantan Ayam Arab pada sampel P1 selama pemeliharaan 2-12 minggu. Maka capaian berat badan kedua jenis ayam secara keseluruhan pada umur 2-12 minggu berat badan ayam Arab $(815,60 \mathrm{~g})$ lebih tinggi dibanding ayam Ketarras $(753,23 \mathrm{~g})$.

Hal ini sesuai pendapat Suprijatna et al. (2006) bahwa berat hidup ayam Arab lebih ringan dibandingkan ayam Ras petelur. Ayam Ketarras yang merupakan hasil persilangan memiliki darah $75 \%$ ayam Arab dan 25\% ayam Ras petelur. Hal utama yang harus diperhatikan untuk memperoleh berat badan yang diharapkan yaitu mutu genetik, lingkungan dan manajemen pemeliharaan. Berat badan ayam Ketarras dan ayam Arab dapat dilihat pada Gambar 2. 


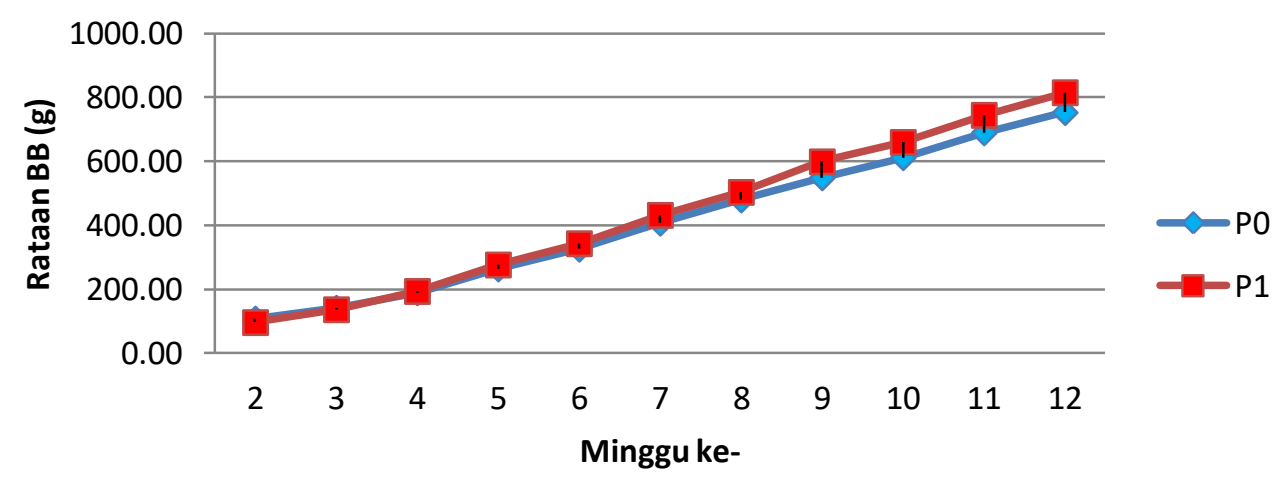

Gambar 2. Grafik rataan berat badan mingguan ayam Ketarras (P0) dan ayam Arab (P1) selama penelitian.

Terlihat pada Gambar 2. bahwa, berat badan masing-masing jenis ayam meningkat dengan bertambahnya umur, sesuai dengan konsumsi ransum selama umur 2-12 minggu.

\section{Pertambahan Berat Badan}

Pertambahan berat badan kumulatif kedua jenis ayam selama penelitian dapat dilihat pada Tabel 5.

Tabel 5. Rataan pertambahan berat badan kumulatif ayam Ketarras dan ayam Arab

\begin{tabular}{|c|c|c|c|}
\hline \multirow{2}{*}{$\begin{array}{l}\text { Minggu } \\
\text { ke- }\end{array}$} & \multicolumn{2}{|c|}{ Pertambahan Berat Badan } & \multirow[b]{2}{*}{ Keterangan } \\
\hline & $\mathrm{P} 0$ & P1 & \\
\hline & \multicolumn{2}{|c|}{------------------- gram/ekor ------------------- } & \\
\hline $2-3$ & $33,67^{\mathrm{a}} \pm 8,02$ & $40,17^{\mathrm{a}} \pm 18,21$ & ns \\
\hline $2-4$ & $81,53^{\mathrm{a}} \pm 11,48$ & $97,43^{b} \pm 16,96$ & $*$ \\
\hline $2-5$ & $156,00^{\mathrm{a}} \pm 25,22$ & $180,17^{b} \pm 18,10$ & * \\
\hline $2-6$ & $217,83^{\mathrm{a}} \pm 25,08$ & $246,73^{b} \pm 27,38$ & * \\
\hline $2-7$ & $299,33^{\mathrm{a}} \pm 30,41$ & $335,37^{b} \pm 37,10$ & $*$ \\
\hline $2-8$ & $371,97^{\mathrm{a}} \pm 42,05$ & $407,13^{\mathrm{a}} \pm 46,42$ & ns \\
\hline $2-9$ & $441,10^{\mathrm{a}} \pm 57,60$ & $502,63^{\mathrm{b}} \pm 54,23$ & * \\
\hline $2-10$ & $504,10^{\mathrm{a}} \pm 49,60$ & $563,37^{\mathrm{b}} \pm 61,38$ & * \\
\hline $2-11$ & $581,73^{\mathrm{a}} \pm 47,44$ & $648,10^{b} \pm 63,29$ & $*$ \\
\hline $2-12$ & $645,07^{\mathrm{a}} \pm 46,28$ & $718,83^{\mathrm{b}} \pm 67,14$ & * \\
\hline
\end{tabular}

Keterangan :

$\mathrm{P} 0=$ Keturunan ayam Arab dengan ayam Arras (Ayam Ketarras)

$\mathrm{P} 1=$ Ayam Arab

$\mathrm{ns}=$ Perlakuan berbeda tidak nyata $(\mathrm{t}$ hitung $<\mathrm{t}$ tabel $)$

* = Perlakuan berbeda nyata ( $\mathrm{t}$ hitung $>\mathrm{t}$ tabel)

Hasil uji $\mathrm{t}$ menunjukkan bahwa pertambahan berat badan kedua jenis ayam berbeda nyata ( $\mathrm{t}$ hitung $>\mathrm{t}$ tabel) kecuali umur 2-3, dan 2-8 minggu. Namun demikian pertambahan berat badan selama umur 2-12 minggu pada ayam Arab nyata 
lebih tinggi dibandingkan ayam Ketarras, yaitu ayam Arab $(718,83 \mathrm{~g})$ dan ayam Ketarras (645,07 g). Menurut Nur (2016), pertambahan berat badan ayam Arras pada minggu 2-12 yaitu (644,92 g), menunjukkan bahwa secara genetik untuk pertambahan berat badan pada minggu 2-4, $2-5,2-6,2-7,2-9,2-10,2-11$, dan 2-12 berbeda nyata antara ayam Ketarras dan ayam Arab. Jumlah konsumsi ransum yang tinggi menghasilkan pertambahan berat badan yang lebih besar. Rasyaf (2011) mengemukakan bahwa ayam terus mengalami peningkatan pertambahan berat badan pada masa pertumbuhan yaitu pada masa awal (masa starter). Ayam yang mengkonsumsi ransum dalam jumlah yang banyak berat badannya lebih tinggi dari pada ayam yang mengkonsumsi ransum dalam jumlah yang sedikit (Suprajatna, 2008). Faktor-faktor yang mempengaruhi pertambahan berat badan unggas antara lain : spesies, jenis ayam, jenis kelamin, dan suhu lingkungan.(Santoso, 2014).

Terdapatnya perbedaan yang nyata pada pertambahan berat badan kedua jenis ayam dapat dilihat pada Gambar 3.

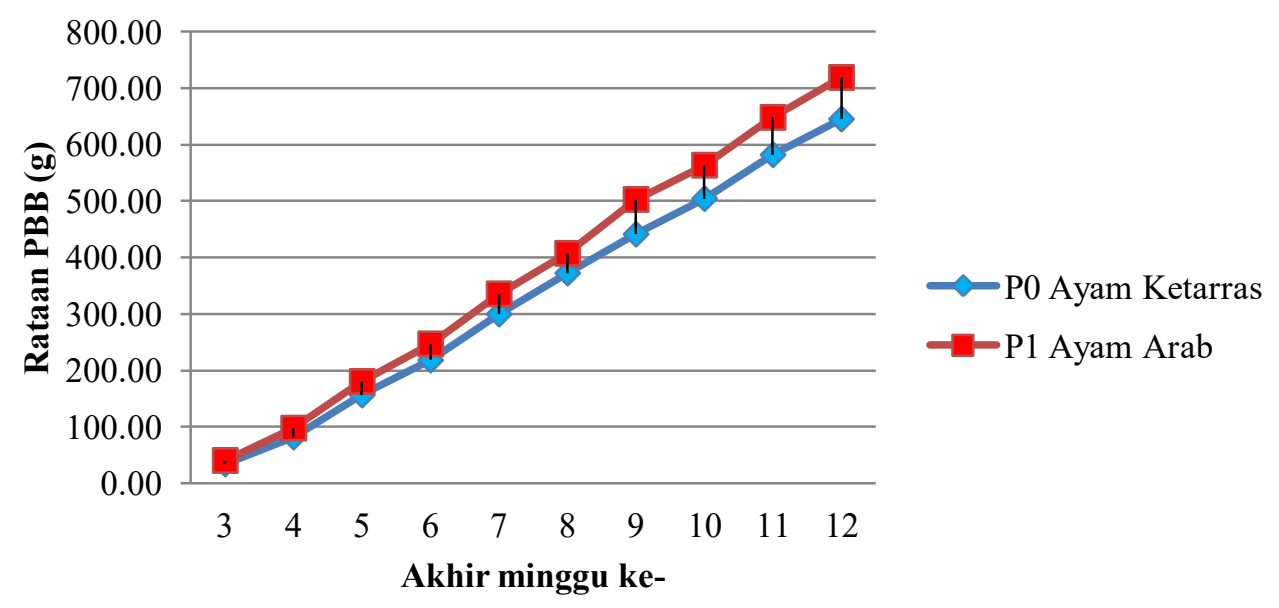

Gambar 3. Grafik pertambahan berat badan kumulatif kedua ayam Ketarras dan ayam Arab.

Terlihat pada Gambar 3.bahwa, pertambahan berat badan kumulatif masing-masing jenis ayam minggu ke 3-12 semakin meningkat dengan bertambahnya umur. Lukman (2005) menyatakan bahwa pertambahan berat badan sangat erat kaitannya dengan peningkatan konsumsi ransum. Konsumsi ransum akan meningkat berdasarkan pertambahan berat badan, artinya semakin laju pertambahan berat badan maka akan semakin besar pula ransum yang akan dikonsumsi oleh ayam tersebut.

\section{Konversi Ransum}

Konversi ransum merupakan salah satu indikator untuk mengukur keberhasilan efisiensi penggunaan ransum yang diberikan dalam menghasilkan daging ataupun berat badan untuk produksi pada fase selanjutnya. Konversi ransum kumulatif kedua jenis ayam selama penelitian dapat dilihat pada Tabel 6 . 
Tabel 6. Konversi ransum kumulatif ayam Ketarras dan ayam Arab

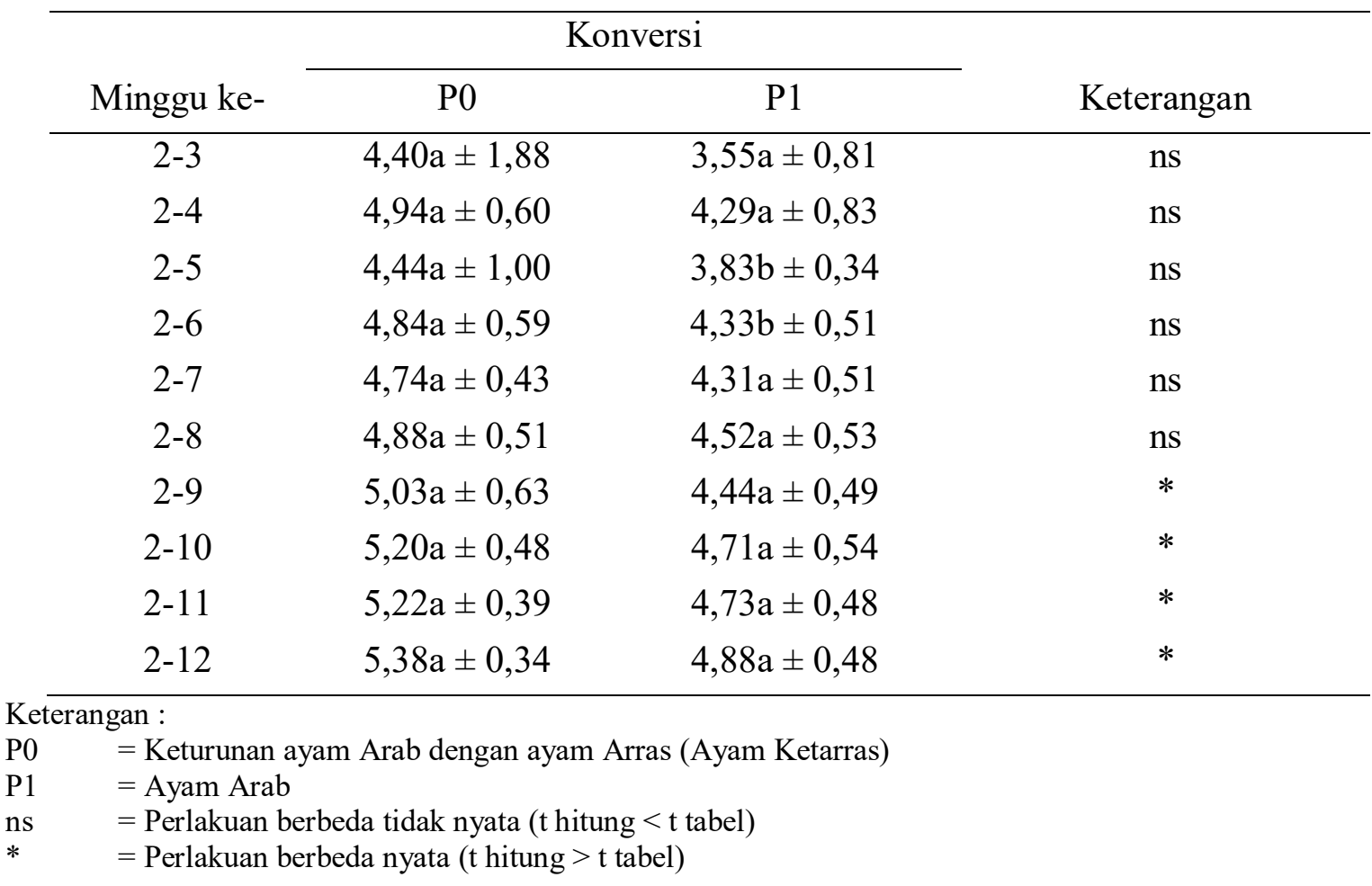

Hasil uji $t$ menunjukkan bahwa konversi ransum kumulatif kedua jenis ayam berbeda tidak nyata ( $\mathrm{t}$ hitung $<\mathrm{t}$ tabel) kecuali pada umur 2-9, 2-10, 2-11, dan 212 minggu. Terlihat pada tabel bahwa, konversi ransum ayam Ketarras lebih tinggi dibanding ayam Arab. Konversi ransum kedua jenis ayam umur 2-12 minggu pada ayam Ketarras $(5,38)$ berbeda nyata lebih tinggi dibandingkan dengan ayam Arab $(4,88)$. Hal ini menunjukkan bahwa efisiensi ransum ayam Arab umur 2-12 minggu lebih baik dibandingkan ayam Ketarras. Menurut Yulianto, (2000) keunggulan ayam Arab selain tahan terhadap penyakit, mudah pemeliharaan, dan mampu bertelur sepanjang tahun, kelebihan lainnya yaitu konsumsi ransum ayam Arab ini lebih sedikit yaitu 90-100 gram/ekor/hari.Rasyaf (2011) menjelaskan semakin rendah konversi ransum adalah semakin baik karena hal itu berarti bahwa ternak lebih efisien dalam menggunakan ransum.Faktor yang mempengaruhi konversi ransum adalah kecepatan pertumbuhan, kandungan energi dalam ransum, terpenuhinya zat nutrisi dalam ransum, suhu lingkungan dan kesehatan.

Terdapatnya perbedaan yang nyata pada konversi ransum kedua jenis ayam selama penelitian dapat dilihat pada Gambar 4. 


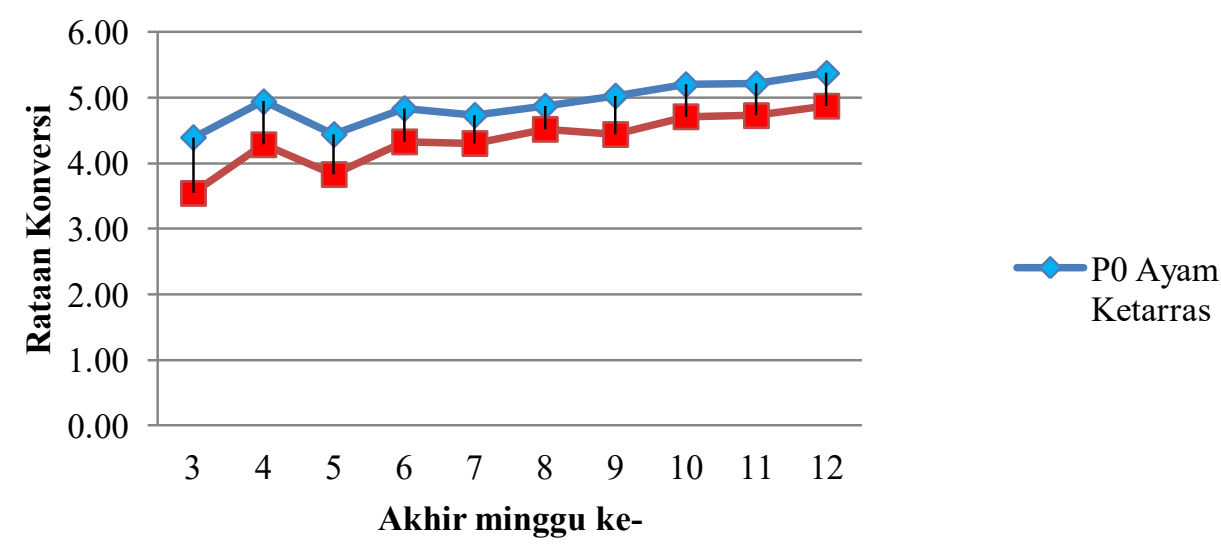

Gambar 4. Grafik konversi ransum kumulatif ayam Ketarras dan ayam Arab.

Terlihat pada Gambar 4. Konversi ransum kumulatif meningkat setiap minggu. Grafik konversi ransum kumulatif tersebut terlihat bahwa konversi ransum kumulatif yang rendah yaitu ayam Arab. Nilai konversi ransum menunjukkan tingkat efisiensi tubuh dalam memanfaatkan ransum yang diberikan. Nilai konversi yang rendah menunjukkan jumlah ransum yang dibutuhkan untuk menaikkan berat badan semakin rendah, sehingga efisiensinya tinggi. Grafik diatas memperlihatkan bahwa semakin bertambahnya umur semakin tinggi konversi ransumnya. Rasyaf (2011) menyatakan bahwa faktor yang mempengaruhi konversi ransum adalah kecepatan pertumbuhan, kandungan energi dalam ransum, terpenuhinya zat nutrisi dalam ransum, suhu lingkungan dan kesehatan.

\section{KESIMPULAN}

Secara kumulatif, selama umur 212 minggu, konsumsi ransum ayam Ketarras dan ayam Arab berbeda tidak nyata sesuai dengan capaian berat badan, pertambahan berat badan, yang lebih rendah pada ayam Ketarras dibanding ayam Arab. Konversi ransum kumulatif ayam Ketarras umur 2-12 minggu nyata lebih tinggi dibanding ayam Arab.

\section{DAFTAR PUSTAKA}

Astuti, M. 2007. Pengantar Ilmu Statistik untuk Peternakan dan Kesehatan Hewan. Binasti Publisher. Bogor

Astuti, N. 2012. Kinerja ayam kampung dengan ransum berbasis konsentrat broiler.Prodi Peternakan Fakultas Agroindustri Universitas Mercu Buana Yogyakarta. Yogyakarta

Binawati, D. K. 2008. Pengaruh laserpunktur terhadap kualitas telur ayam Arab. Journal of Science 2 (1): 28-34.

Badan Pusat Statistik. Jakarta Pusat. 2016. Pendataan Konsumsi Protein Hewani 2016. Jakarta Pusat : Badan Pusat Statistik.

Darmana, W. dan M. Sitanggang. 2002. Meningkatkan Produktivitas Ayam 
Arab Petelur. Agromedia Pustaka. Jakarta.

Diana. 2012. Performans ayam Arab(Gallus turcicus) periode starter yang diberi ransum dengan level protein dan energi yang berbeda. Skripsi. Program Studi Peternakan Fakultas Pertanian Dan Peternakan Universitas Islam Negeri Sultan Syarif Kasim Riau Pekanbaru.

Hartadi. H. S., Reksohardiprojo dan A. D. Tilman. 2005. Tabel Komposisi Pakan untuk Indonesia. Cetakan ke IV. Gadjah Mada University.

Iskandar, S., dan T. Sartika T. 2008. Respon Pertumbuhan Ayam Kampung dan Ayam Silangan Pelung terhadap Ransum Berbeda Kandungan Protein. Balai Penelitian Ternak. Bogor.

Lukman, H. 2005. Evaluasi pemberian feed aditive alami berupa campuran herbal, probiotik, dan prebiotik terhadap performans, karkas dan lemak abdominal, serta HDL, LDL daging. Skripsi. Departemen Ilmu Nutrisi dan Teknologi Pakan. Institut Pertanian Bogor. Bogor.

National Research Council. 1994. Nutrient requirement of poultry. Ninth revised edition. printing and publishing national academy of science. Washington.

Nur, A. M. 2016. Performans Pertumbuhan Keturunan Ayam Arab dengan Ayam Ras Petelur (Ayam Arras) dan Ayam Arab Umur 2-12
Minggu [Skripsi]. Fakultas Pertanian. UNIB. Bengkulu.

Rasyaf, M. 2008. Beternak Ayam Petelur. Penebar Swadaya. Jakarta.

Rasyaf, M. 2011. Paduan Beternak Ayam Pedaging.Cetakan ke 4. Penebar Swadaya. Jakarta.

Sukarini. N. E., dan A. Rifai. 2011. Pengaruh penambahan berbagai tepung hijauan terhadap performans produksi ayam Arab. Akademi Peternakan Karanganyar. Semarang.

Sulandari, S., M. S. A. Zein, S. Paryanti, T. Sartika, M. Astuti, T. Widjastuti, E. Sudjana, S. Darana, I. Setiawan dan D. Garnida. 2007. Sumberdaya genetik ayam lokal Indonesia. Keanekaragaman Sumberdaya Hayati Ayam Lokal Indonesia: Manfaat dan Potensi. Pusat Penelitian Biologi Lembaga Ilmu Pengetahuan Indonesia, Jakarta. Hal : 45-67.

Suprijatna, E., L. D. Mahfudz, dan W. Sarengat. 2006. Performans produksi telur ayam arab akibat pemberian ransum berbeda taraf protein saat pertumbuhan. Fakultas Peternakan Universitas Diponegoro. Semarang.

Suprajatna, E., U. Atmomarsono dan R. Kartasudjana. 2008. Ilmu Dasar Ternak Unggas. Penebar Swadaya. Jakarta.

Yulianto, H. 2000. Ayam Arab berpotensi dikembangkan secara komersial. Poultry Indonesia. Edisi Juni, No. 242/57. 